\title{
The Correlation Between Caring Behavior and Length of Stay of Patients in Surgical Inpatient Department of Ajibarang Hospital
}

\author{
$1^{\text {st }}$ Mufri Datun Alfiyah \\ Undergraduate Science of Nursing \\ Student \\ Faculty of Health Science, \\ Harapan Bangsa University \\ Purwokerto, Indonesia \\ mufridatunalfiyah04@gmail.com
}

\author{
$2^{\text {nd }}$ Indri Heri Susanti \\ Nursing Lecturer \\ Faculty of Health Science, \\ Harapan Bangsa \\ University \\ Purwokerto, Indonesia \\ indriherisusanti@uhb.ac.id
}

\author{
$3^{\text {rd }}$ Rahmaya Nova $\mathrm{H}$ \\ Nursing Lecturer \\ Faculty of Health Science, \\ Harapan Bangsa \\ University \\ Purwokerto, Indonesia \\ mayanova2005@gmail.com
}

\author{
$4^{\text {th }} \quad$ Yuris Tri Naili \\ Nursing Lecturer \\ Faculty of Health Science, \\ Harapan Bangsa \\ University \\ Purwokerto, Indonesia \\ yuris@uhb.ac.id
}

Length of Stay (LOS) is one of the indicators of quality service in a hospital. Length of Stay is the duration of treatment days in hospital in one period of nursing. One of the factors Influencing LOS is the care giver, in this case is caring behavior from nurses.

The purpose of this research was to know the correlation between caring behaviors and LOS of Patients in Surgical Inpatient Department of Ajibarang Hospital.

This research used cross sectional. The samples were taken by using accidental sampling as much as 56 Patients allowed to discharge. The instruments used were questionnaire of caring behavior Adopted from the original questionnaire of Caring Behavior Inventory I (Wolf, 1998) and the observation sheet of LOS. The statistics test of univariate and bivariate used was Spearman rank.

The result Showed that 46 respondents (82.1\%) Considered that nurses' caring behavior in Ajibarang hospital was good. Exactly 37 respondents (66.1\%) had short length of stay (<5days). So, it can be concluded that there was a significant correlation between caring behavior and LOS in surgical inpatient department in Ajibarang Hospital with pvalue $0.000<\alpha 0.05$.

Keywords: caring behavior, length of stay (LOS)

\section{INTRODUCTION}

Length of stay is one indicator of the quality of medical services provided by the hospital to the patient (quality of patient care). Length Of Stay is to show how many days a patient is hospitalized in a treatment period. The units for hospitalization was the day, while for calculating the length of stay is by calculating the difference between the date of return (out of the hospital both living and dead) and the date of hospitals [1].

Factors that affect LOS length of stay of patients in hospitals, among others: the medical condition of the patient, the economy, types of cases of the disease, type of action, and therapeutic action planning, personnel involved in the care and hospital administration policy [1]. Importance LOS little affect on the medical side, namely The little longer hospitalizations then in this case show the quality of the performance of the medical has been quite good, in terms of economical The shorter length of stay in hospital, meant to reduce the cost (if the patient pay for itself ) [2] .

Caring as a moral imperative (form moral) so that nurses should be composed of people who are morally good and have concern for the health of patients, which maintain the dignity and respect for the patient as a human being, it means to be a nurse means must dare to be something special [3]. Factors influencing factors include caring individual that is based on ability, background and demographic, psychological factors which reflect a person feels about something and understanding attitude, organizational factors is an open system to interact with its environment.

The better the behavior of caring nurses in providing nursing care services, patient or family is getting excited in receiving the service, means the therapeutic relationship nurse and the client is getting built up. Patients were satisfied with nurse-friendly, easy smile, polite and pay attention. Expressions such patients in accordance with the theory that caring is a nursing practice where nurses help clients recover from his illness [4].

Based on observations of pre-survey conducted in hospitals Ajibarang in December 2018, LOS retrieve data in 2017 in the surgical ward inpatient ranges average between 35 days, and then for his caring behavior conducted interviews to 10 patients in the room inpatient surgical ward, who asked a question about whether the nurses were always using the principles of $5 \mathrm{~S}$ (smiles, greetings, greetings, polite, mannered), nurses constantly monitor the patient's condition or not, and whether the behavior of the nurses will affect the duration of treatment, taken at random, from 10 patients, 6 of them say less treated well, nurses are not fully sincere to provide optimum service, nurses are still rarely smiles to patients, and caregivers are still rarely monitor the condition 
(44.6\%). Gender predominantly women of 31 respondents

and the patient's progress,so that the disease can affect the patient's recovery, which would result in increased length of hospitalization, and 4 patients said nurses had behaved and caring towards patients.

The purpose of this research was to know the correlation between caring behaviors and LOS of Patients in Surgical Inpatient Department of Ajibarang Hospital.

\section{METHODOLOGY}

The method used in this study was a correlation study method with cross sectional approach. The research was conducted on 15-30 July 2019.

The population in this study were hospital surgical ward patients Ajibarang by using accidental sampling. Accidental sampling was done by taking the case or the respondent accidental or provided somewhere within the context of research, with the number of respondents 56 people.

The research instrument was a questionnaire Caring Behavior Inventory (CBI) and LOS observation sheet, data were analyzed using univariate analysis of the frequency distribution and bivariate analysis were used in this study using the Spearman rank test.

\section{FINDINGS AND DISCUSSION}

\section{Table 1}

Respondent characteristics include age, sex, in-room hospital inpatient surgical ward Ajibarang Month of August 2019

\begin{tabular}{lll}
\hline Classification & F & Percentage $(\%)$ \\
\hline Age & & \\
Early teens (12-17) & 3 & 5.4 \\
Early adulthood (18-40) & 18 & 32.1 \\
Middle age (41-60) & 25 & 44.6 \\
Older adults $(>60)$ & 10 & 17.9 \\
Gender & & \\
Male & 25 & 44.6 \\
Woman & 31 & 55.4 \\
length of & & \\
3 days & 19 & 33.9 \\
4 days & 15 & 26.8 \\
5 days & 3 & 5.4 \\
6 days & 14 & 26.8 \\
7 days & 5 & 7.1 \\
& & \\
\hline Total & 56 & 100.0 \\
\hline
\end{tabular}

According to the table 1, the caring behavior in the hospital inpatient surgical ward Ajibarang based on the age of respondents mostly middle age of 25 respondents
$(55.4 \%)$. Length of stay the majority for 3 days were 19 respondents $(33.9 \%)$. Type of disease was a degenerative disease largely of 38 respondents $(67.9 \%)$.

\section{Table 2}

The behavior of nurses caring for patients in the inpatient surgical wards in hospitals Ajibarang August 2019

\begin{tabular}{lll}
\hline Caring Behaviors & Frequency & Percentage $(\%)$ \\
\hline Caring & 47 & 83.9 \\
Caring enough & 9 & 16.1 \\
not Caring & 0 & 0 \\
\hline Total & 56 & 100.0 \\
\hline$(\mathrm{N}=56)$ &
\end{tabular}

Based on the results in Table 2, it indicates that almost all respondents consider caring behavior nurses in hospital inpatient surgical ward Ajibarang own good of 47 respondents $(83.9 \%)$.

Table 3

Length Of Stay (LOS) in-patient surgical wards in hospitals Ajibarang August 2019

\begin{tabular}{lll}
\hline Length Of Stay (LOS) & Frequency & Percentage (\%) \\
\hline Long & 19 & 33.9 \\
Not long & 37 & 66.1 \\
\hline Total & 56 & 100.0 \\
$\mathrm{n}=56$ & &
\end{tabular}

Based on the results in Table 3, it indicates that most respondents have a length of stay which are short $(<5$ days $)$ of 37 respondents $(66.1 \%)$. 
Table 4

Relations with the Length of stay nurse caring behaviors in hospitalized patients surgical wards in hospitals Ajibarang August

\begin{tabular}{|c|c|c|c|c|c|c|c|c|}
\hline \multirow{3}{*}{ Caring Behaviors } & \multicolumn{4}{|c|}{$L O S$} & \multirow{2}{*}{\multicolumn{2}{|c|}{ Total }} & \multirow[t]{3}{*}{$\mathrm{CC}$} & \multirow[t]{3}{*}{$p$-value } \\
\hline & \multicolumn{2}{|c|}{ Long } & \multicolumn{2}{|c|}{ Not long } & & & & \\
\hline & $\mathrm{F}$ & $\%$ & $\mathrm{~F}$ & $\%$ & $\mathrm{~F}$ & $\%$ & & \\
\hline Caring well & 11 & 19.6 & 35 & 62.5 & 47 & 83.9 & -0.508 & 0,000 \\
\hline Caring enough & 8 & 14.3 & 2 & 3.6 & 9 & 16.1 & & \\
\hline not Caring & 0 & 0.0 & 0 & 0.0 & 0 & 0.0 & & \\
\hline Total & 19 & 33.9 & 37 & 66.1 & 56 & 100.0 & & \\
\hline
\end{tabular}

$\mathrm{n}=56$

Based on the results in Table 4, it shows that the test spearmen obtained rank p-value of $0.000(<0.05)$ so that Ha Ho accepted and rejected, which means that there is a relationship between a caring behavior and length of stay (LOS) in the inpatient surgical ward of Ajibarang hospital. The strength of the correlation was a negative correlation direction, the higher the caring behavior then the length of stay is getting shorter. relations between the two variables was in the opposite direction which means that a high caring behavior will accelerate the treatment period.

\section{A. Characteristics of Respondents}

According to the table 1 the type of diseases most of respondent are the type of degenerative disease 38 respondents $(67.9 \%)$ who have age middle age is 41-60 years as many as 25 respondents $(44.6 \%)$ who suffer from diseases such as prostate, hernia, DM, abscess , cataracts, and diseases of the glands, from exposure to the above shows that this age of patients requiring treatment that is full or needs complete in all aspects. Age is an indicator of a change that will happen to someone. Age describes the experience in a person so that there is a diversity of action based on the age of owned [5]. This research was in line with research from Tamamilang (2018) [6] about the relationship between age with hypertension who get results $\mathrm{p}$-value $=0.003 \alpha$ $=0,05$, which means there is a significant relationship between age and hiprtensi, hypertension here is a degenerative disease. Gender predominantly women of 31 respondents $(55.4 \%)$, with diseases such as glands in certain body parts, diabetes, hemorrhoids and fractures, this is in line with research Rantung, 2015 [7] concerning "the relationship of self-care and quality of life of patients diabetes mellitus (DM) "getting results the majority $(71.2 \%)$ of female respondents were diabetic 


\section{Caring Behaviors relationship with Length Of Stay (LOS)}

The test results of data analysis in the research that has been done on the relationship of caring behavior with the length of stay (LOS) in the hospital inpatient surgical ward Ajibarang showed a p-value of $0.000<\alpha$ 0.05 , which means there is a significant relationship between caring behavior by length of stay (LOS) in the hospital inpatient Ajibarang. Koelasi strength of the relationship was to the value of -0.508 and a negative correlation direction, relations between the two variables have the opposite direction of relationship caring behavior where the better the treatment duration or length of stay will be even lower, so caring less will lead to increased hospitalization period.

Based on the results of a study of inpatient surgical wards in hospitals Ajibarang researchers assume that the period of treatment time could be due to a lack of caring behavior of nurses such as the lack of attention so that the patient will feel saturated which will extend the duration of the treatment, it is in line with research from Anjaryani (2009) [12] who said patients with treatment time will tend to be saturated with the treatment situation is done and the patient will tend to get bored with the treatments performed by nurses and doctors, in addition to the stress of nurses will also affect the behavior of caring nurse due to the workload of the excess that would affect length of treatment, this is evidenced by research Desima (2013) [13] about the stress levels of nurses with nurses caring behavior. Perwira, (2011) [14] explained that the length of stay was one of the indicators of quality assessment, quality assessment of good nursing care is a short length of stay so that patients with a short time can be declared cured and can be discharged. This was in line with research Fadilah (2016) [15] on "caring relationship with a nurse in a nursing care length of stay in hospitals Salatiga" test based on rank spearmen found a significant correlation with the value of $p=0.009<\alpha 0.05$.

\section{CONCLUSION}

Based on the results of research and discussion the severity of the disease, when the illness was severe illness, it will tend to have the care process and a longer recovery, although these patients had no complications, the type of action also affects length of treatment, and delay in administration. This was supported by previous studies conducted by the officer, (2011) length of a patient associated with the patient's diagnosis, seen with primary diagnosis, comorbid diagnoses and complications. can be concluded as follows:

1. Most nurses' caring behavior (82.1\%) in hospitals Ajibarang were good.

2. Most of respondents $(66.1 \%)$ had a length of stay that which were not long ( $<5$ days).

3. There was a significant correlation between caring behavior with the length of stay (LOS) for patients in the 
inpatient surgical ward of Ajibarang hospital, as indicated by the test results obtained with Spearman rank with pvalue of $0.000(\alpha<0.05)$.

\section{REFERENCES}

[1] I. Wartawan, “Analisis Lama Hari Rawat Pasien Yang Menjalani Pembedahan Di Ruang Rawat Inap Bedah Kelas III RSUP Sanglah Denpasar," Tesis, 2012.

[2] R. Yuliyanti, D, “Analisis Deskritif Lama Perawatan, Karakteristik Pasien Dan Pembiayaan Pada Kasus Hematologi Dengan Tindakan Kemoterapi Pasien Bpjs Non Pbi Pada Tahun 2015 Di Rsup Dr Kariadi Semarang," J. Keperawatan, no. 1, 2015.

[3] M. Dwidiyanti, Caring. Semarang: Hasanii, 2007.

[4] P. A. Potter and A. G. Perry, Fundamental of Nursing, 7th ed. Jakarta: Salemba Medika, 2010.

[5] Notoatmodjo, Metodologi Penelitian Kesehatan. Jakarta: PT Rineka Citra, 2010.

[6] Tamamilang, "Hubungan Antara Umur Dan Aktifitas Fisik Dengan Derajat Hipertensi Di Kota Bitung," J.

Kesehat. Masy., vol. 7, no. 5, 2018.

[7] Rantung, "Hubungan Self Care Dengan Kualitas Hidup Pasien DM," 2015.

[8] R. Napitupulu, "Prevalensi Hernia Inguinalis pada Anak di RSUP H. Adam Malik," 2010.

[9] D. N. MONY, "Hubungan sikap Caring perawat dengan kepuasan pasien rawat inapkelas III Di Rumah Sakit," 2014.

[10] E. Umayah, "Hubungan Perilaku Caring Perawat Dengan Tingkat Kepuasan Pasien Di Bangsal Rawat Inap Wardah Rs Pku Muhammadiyah Gamping," 2012.

[11] P. A. Potter and A. G. Perry, "Fundamentals of Nursing," Fundam. Nurs., pp. 49-49, 2009.

[12] W. . Anjaryani, "Kepuasan Pasien Rawat Inap Terhadap Pelayanan Perawat Di Rumah Sakit Tugurejo Semarang," Tesis, 2009.

[13] R. Desima, "TINGKAT STRES KERJA PERAWAT DENGAN PERILAKU CARING PERAWAT Nurse working stress with nurses' caring behavior," $J$. Keperawatan, vol. 4, no. 1, pp. 43-55, 2013.

[14] I. Perwira, "Faktor- Faktor Yang Mempengaruhi Lama Rawat Pada Pasien Yang Terinfeksi Virus Dengue di RSUP Persahabatan Jakarta Timur," tesis, 2011.

[15] Fadilah, "Hubungan Caring Perawat Dalam

Pelayanan Keperawatan Dengan Lama Rawat Inap Di RSUD Salatiga," J. Keperawatan, 2016. 